\title{
The potential of small-scale SNG production from biomass gasification
}

\author{
Sebastian Fendt • Alexander Tremel • \\ Matthias Gaderer • Hartmut Spliethoff
}

Received: 23 December 2011 /Revised: 5 March 2012 / Accepted: 6 March 2012

(C) Springer-Verlag 2012

\begin{abstract}
Synthetic natural gas (SNG) can be produced from biomass by thermochemical gasification and subsequent synthesis gas methanation and gas processing. For an industrial-scale process with high efficiency (up to $74 \%$; Rönsch et al. in VGB PowerTech 5:110-116, 2008), the large plant size is associated with a number of disadvantages such as a high biomass transportation volume and local environmental impacts. Small distributed SNG production units would minimize these negative aspects but are expected to cause lower efficiency. In order to show the potential of a small-scale SNG solution, different process chain configurations are simulated using Aspen Plus software. Combined heat and power generation via gasification and direct product gas conversion in a gas engine is compared to a SNG route, where the product gas is further cleaned, converted, and upgraded to SNG. Different gasification technologies (co-current fixed bed, countercurrent fixed bed, and dual fluidized bed) are evaluated. The SNG route is based on a dual fluidized bed gasification, subsequent methanation, and injection into the natural gas grid. As an outcome of the simulations, the efficiencies are calculated with special focus on heat integration and utilization. A maximized utilization of the released process heat results in a strong overall efficiency increase. Depending on the local heat utilization, gasification with subsequent methanation has an advantage compared to direct local power generation. The overall efficiency of the SNG option
\end{abstract}

This paper was originally presented at the International Conference on Polygeneration Strategies 2011 (ICPS11) in Vienna.

S. Fendt $(\bowtie) \cdot$ A. Tremel $\cdot$ M. Gaderer $\cdot$ H. Spliethoff Institute for Energy Systems, Technische Universität München,

Boltzmannstr. 15,

85748 Garching, Germany

e-mail: sebastian.fendt@tum.de is found to be up to $73.9 \%$, which is within the range of the fluidized bed gasification option. The crucial factor for high efficiency, and thus for an economic operation, is the heat demand at the location. With even a small constant heat demand, the SNG solution becomes very competitive as some of the heat otherwise generated on-site is translated into chemical energy and carried to a power generation location elsewhere. It has been shown that SNG production subsequent of a small-scale fluidized bed gasifier can very well be efficient in both energetic and economic regards. The most important and crucial parameter is the heat utilization on-site and thus the local heat demand characteristics.

Keywords SNG · Gasification · Biomass · Simulation · Heat utilization

\begin{tabular}{|c|c|}
\hline \multicolumn{2}{|c|}{ Abbreviations } \\
\hline SNG & Synthetic natural gas \\
\hline CHP & Combined heat and power \\
\hline ССРP & Combined cycle power plant \\
\hline REA & Restricted equilibrium approach \\
\hline LHV & Lower heating value \\
\hline $\mathrm{wt} \%$ & Weight percent \\
\hline$c_{\mathrm{el}}$ & $\begin{array}{l}\text { Power production costs (in euro cents per } \\
\text { kilowatt hour of electricity) }\end{array}$ \\
\hline$c_{\mathrm{a}}$ & Annual costs (euros) \\
\hline$r_{\text {on }}$ & Revenues on-site heat utilization (euros) \\
\hline$r_{\text {off }}$ & Revenues off-site heat utilization (euros) \\
\hline$Q_{\mathrm{el}}$ & $\begin{array}{l}\text { Net power generation per year (kilowatt hours } \\
\text { of electricity) }\end{array}$ \\
\hline$P_{\text {int }}$ & Internal power consumption (kilowatts) \\
\hline$\dot{m}$ & $\begin{array}{l}\text { Mass flow (product gas or biomass) (kilograms } \\
\text { per second) }\end{array}$ \\
\hline 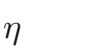 & Efficiency (percent) \\
\hline
\end{tabular}




\section{Introduction}

The urgent demand for greenhouse gas reduction and safe, reliable as well as sustainable energy supply in general promotes renewable energy technologies. In this context, the utilization of biomass for heat and power generation is an option which not only lowers the dependency on fossil fuels but also reduces $\mathrm{CO}_{2}$ emissions.

In particular, the production of synthetic natural gas (SNG) from biomass is a promising option for future renewable energy production. So far, the electrical grid has been used for the distribution of energy. By using the existing natural gas grid, energy from biomass can be stored and distributed in a very efficient way. The production of electricity is independent from the direct utilization of biomass and can be adapted to the present power demand.

Therefore, SNG is considered a perfect complement to balance fluctuating electricity production from other renewable sources like solar power or wind. Furthermore, the SNG route resolves some of the problems often caused by direct biomass utilization, like localized heat generation and its energy recovery.

While fixed and fluidized bed gasification and combustion have become state-of-the-art technology for biomass applications in small- and medium-scale facilities, the technology of SNG production is still in its research stage [1]. Over the last years, various fixed bed and fluidized bed gasifiers have been coupled to gas engines or gas turbines for direct combined heat and power generation.

The SNG process is also based on gasification technology and is therefore a viable alternative. A broad consensus in the literature and the industry suggests that the allothermal fluidized bed configuration is the most promising gasification option for further SNG production [2-5]. Figure 1 shows the process steps for SNG production mounted downstream from a fluidized bed gasifier with subsequent synthesis gas cleaning, methanation, and gas processing.

\section{Concept and methodology}

In order to show the potential of small-scale SNG production $\left(10 \mathrm{MW}_{\text {th,fuel }}\right)$ from biomass, four different process configurations based on biomass gasification are simulated. Process chains are developed for three gasifier types (cocurrent and countercurrent fixed bed as well as fluidized

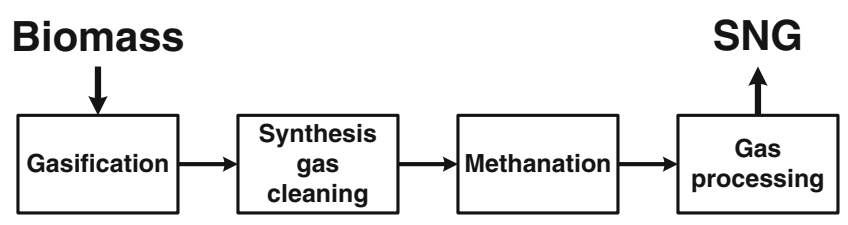

Fig. 1 Process steps for SNG production (adapted from [6]) bed) and subsequently transformed into simulation models using the simulation software Aspen Plus. Table 1 shows an overview of the five considered process chain configurations $\mathrm{A}$ to $\mathrm{E}$.

Power generation is modeled by applying a gas engine in options A-D. In option E, SNG is fed to the natural gas grid and converted to electricity in a large combined cycle plant (co-firing). Figure 2 gives a visual overview of these options with special attention to the heat production and possible utilization and the power generation.

Process parameters for the simulation are validated by the literature and show good agreement with reported data from suppliers. Process options are compared in terms of energy efficiency and electricity production costs.

\section{Process simulation}

The simulation software Aspen Plus performs material and energy balance calculations. User-defined subroutines can be implemented using FORTRAN and Excel-based codes.

Gasifiers are designed for a thermal fuel input of $10 \mathrm{MW}$. This translates to a wet biomass feed (beech wood) of $0.75 \mathrm{~kg} / \mathrm{s}$ with a lower heating value of $13,226 \mathrm{~kJ} / \mathrm{kg}$. The outlet product gas stream (synthesis gas) is fixed at $30{ }^{\circ} \mathrm{C}$ and 5 bar, favoring its utilization in a subsequent gas engine and ensuring comparability between them.

Heat losses are considered for both gasifiers, determined through heat transfer calculations based on reactor volumes and pressure levels for each process and for any process equipment/blocks, respectively.

\subsection{Fixed bed gasification}

The two fixed bed gasification options (co-current and countercurrent) are realized using similar components with only small differences in the sequence of process parts, caused by the subsiding reaction processes. The simulations further contain a subsequent product gas conditioning section. The power generation is carried out in a gas engine, modeled as "black-box unit" by a typical efficiency factor. Both gasifiers are air-blown and under atmospheric pressure.

Table 1 Process options (A-E)

\begin{tabular}{lll}
\hline \multicolumn{1}{c}{ Gasification technology } & Application/utilization \\
\hline A & Fixed bed (co-current) & CHP (gas engine) \\
B Fixed bed (countercurrent) & CHP (gas engine) \\
C & Dual fluidized bed & CHP (gas engine) \\
D Dual fluidized bed & SNG (methanation) + subsequent CHP \\
E & Dual fluidized bed & SNG (methanation) + combined cycle \\
\hline
\end{tabular}


Fig. 2 Visual overview of process options $A$ to $E$ with power and heat production

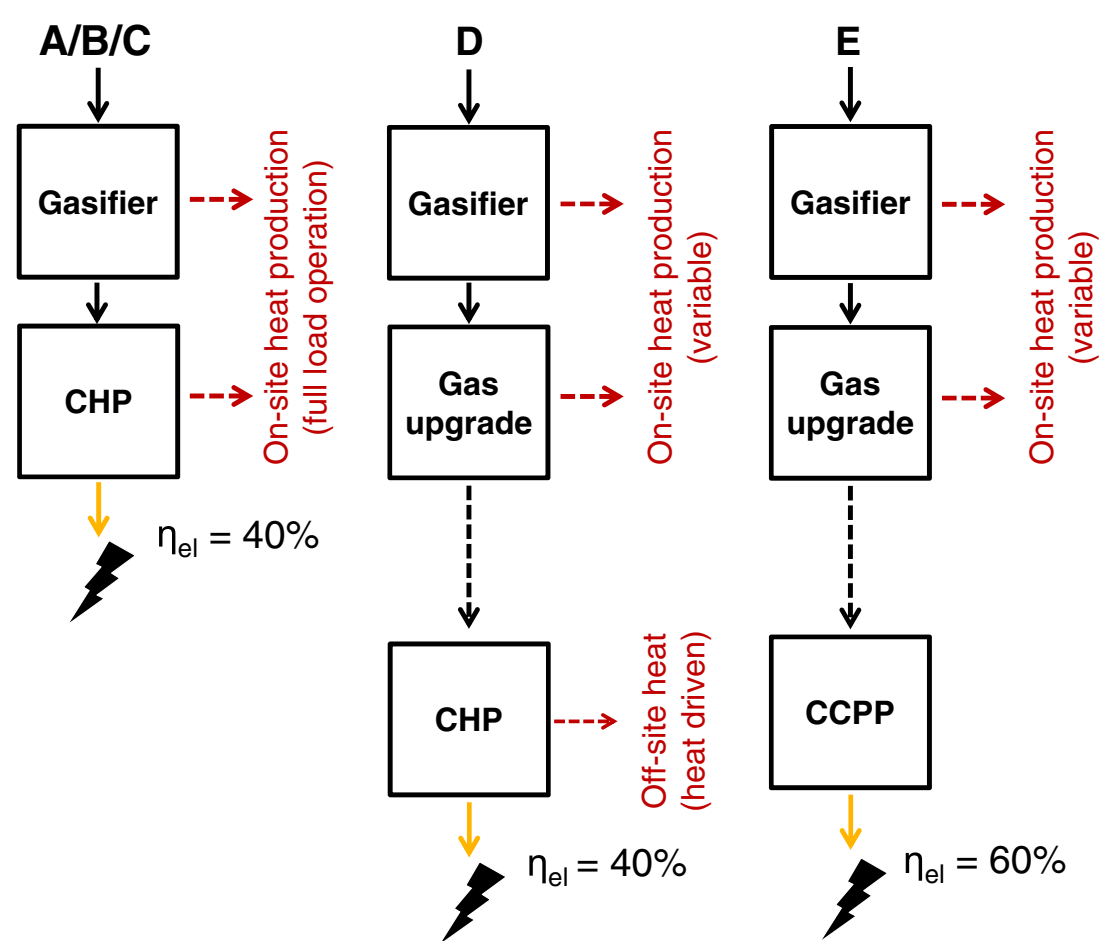

The co-current fixed bed option (A) is shown in Fig. 3. The wet biomass stream is fed to a drying zone, where the moisture is vaporized and separated.

The gasifier is simulated by three Aspen Plus blocks labeled as PYR, OX, and Gasifier. The pyrolysis reactor (PYR) simulated by a RYield reactor decomposes the feed into its elemental composition according to the ultimate analysis of the biomass. Part of the carbon and hydrogen are later separated and externally converted to methane and naphthalene, which is necessary to adjust a realistic gas mixture regarding the tar and methane levels. To simplify, naphthalene is chosen to represent the tar content. The main stream together with the water vapor is further fed to the oxidation reactor $(\mathrm{OX})$, modeled as an equilibrium reactor where part of the stream is burned at $1,000{ }^{\circ} \mathrm{C}$. The actual gasification reaction (Gasifier) is modeled as an RGibbs reactor with a restricted equilibrium approach (REA) at
$850{ }^{\circ} \mathrm{C}$. Chemical equilibrium is assumed for the gas composition but at a different lower temperature, which is determined by fitting simulated gas compositions to experimental data (for exact description, see [6]).

After the gasifier, ash is removed and the remaining, particle-free product gas is further conditioned in the subsequent gas conditioning phase including the removal of waste substances like tars, sulfur, and chloride components (note: Fig. 3 shows just one combined "cleaner" unit for reasons of clarity only) as well as cooling and two-stage compression to the required product gas conditions of $5 \mathrm{bar}$ and $30^{\circ} \mathrm{C}$. The tar removal is simplified by a combined cooling (to $60^{\circ} \mathrm{C}$ ) and separation unit representing a real tar scrubbing system (usually with an output temperature around $60{ }^{\circ} \mathrm{C}$ ). Excess water is removed by condensation.

The countercurrent fixed bed simulation (B) differs merely in the sequence of the Aspen Plus blocks (see Fig. 4). In this
Fig. 3 Simplified process simulation flowsheet of co-current fixed bed gasification

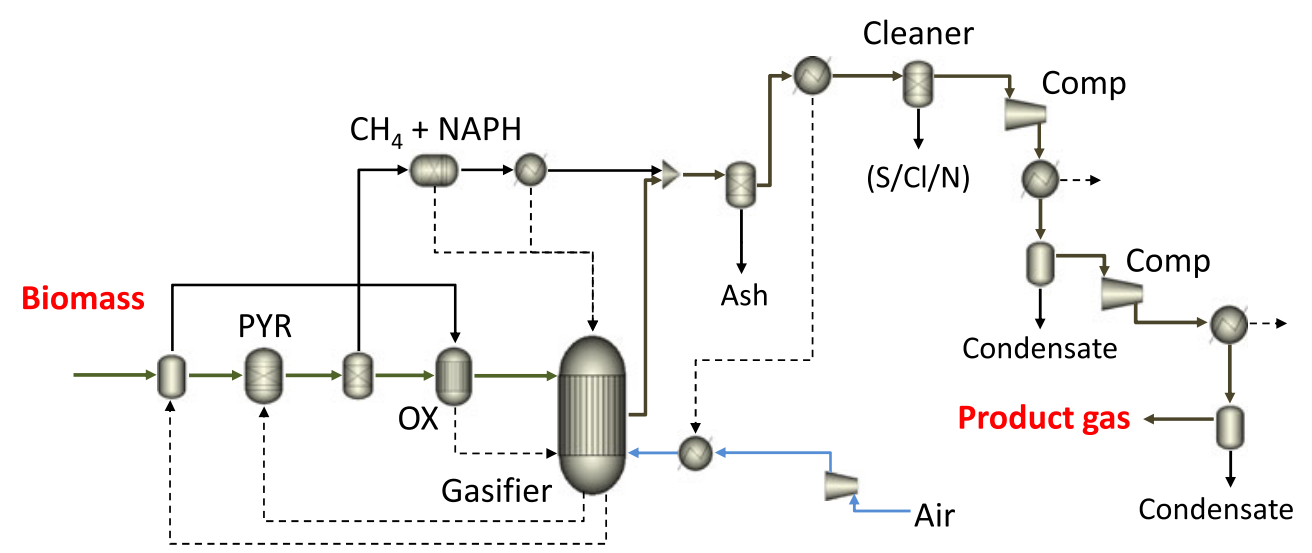


Fig. 4 Simplified process simulation flowsheet of countercurrent fixed bed gasification

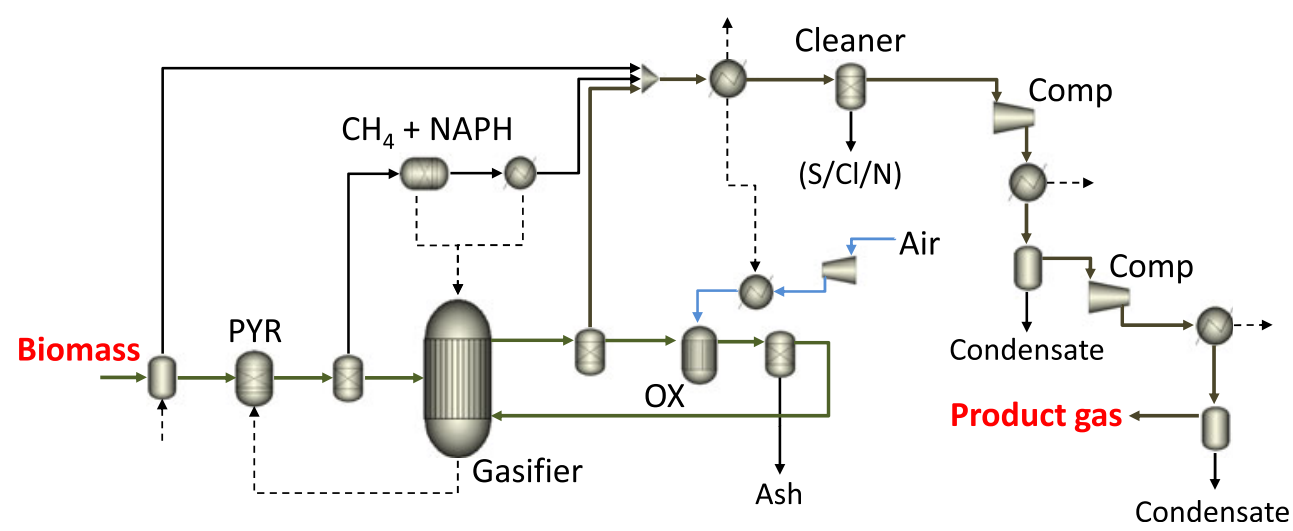

case, the vaporized water is separated from the biomass stream and merged into the product gas stream after gasification. Thus, the water does not influence the subsequent gasification processes in accordance with the real configuration.

Dry biomass enters the pyrolysis zone where the conversion to char and pyrolysis gases occurs. Some of the carbon and hydrogen are separated and externally converted to methane and naphthalene, respectively. The remaining stream is directly fed to the actual gasification reactor (RGibbs), modeled with a REA at $850^{\circ} \mathrm{C}$. The residual, unconverted carbon is fed to the oxidation reactor (equilibrium reactor) where it is burned together with preheated air. Recycled to the gasifier, the hot flue gas delivers the heat required for endothermic gasification. The mass flow of combustion air is adjusted to a gasification temperature of $700^{\circ} \mathrm{C}$. The final product gas conditioning unit matches the aforementioned co-current bed option.

\subsection{Fluidized bed gasification}

The fluidized bed gasification (C) is designed with circulating bed material in two separate fluidized beds (see Fig. 5).
The combustion bed provides the heat supply for the circulating bed material. This configuration prevents a dilution of the product gas with nitrogen from the air, which guarantees a high caloric synthesis gas. However, the second fluidized bed increases the complexity of the system. In order to compare the simulation with reality, the simulation is modeled on the basis of the reference plant located in Güssing (Austria), where the literature provides well-researched data [7].

Besides the gasifier, the simulation concept contains a flue gas cooling section, subsequent product gas conditioning, and a process steam production system. Figure 5 shows the process configuration with the individual parts of the simulation.

The central gasifier is modeled as an equilibrium reactor where the product gas composition is adapted via a REA. Biomass feed is connected to a decomposer (pyrolysis) and downstream modified with an external methanation reactor for additional methane generation. Thus, the gas composition modeled can be adjusted to real gas data from the reference gasifier (Güssing). In addition, the tar issue is met by an external tar reactor which produces tar or naphthalene, respectively, in the same amount that the literature
Fig. 5 Simplified process simulation flowsheet of fluidized bed gasification (the asterisk indicates the link between the gasifier and the subsequent SNG upgrading steps for options $D$ and $E$ )

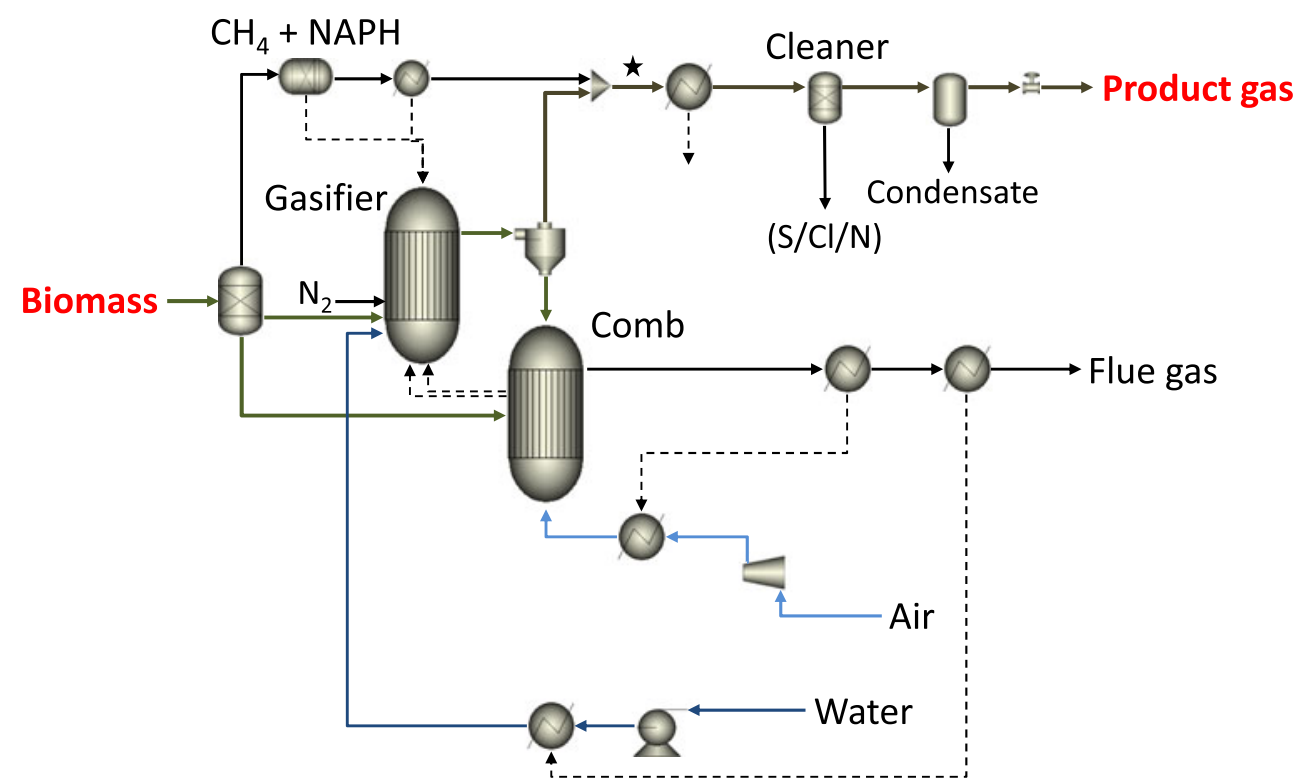


suggests from the carbon feedstock (about $5 \mathrm{~g} / \mathrm{Nm}^{3}$ wet gas). Ninety percent of the carbon is converted in the gasifier, which leaves $10 \%$ char for the combustion with preheated air and some additional biomass in the second fluidized bed. For heat generation, the mixture is burned under excess air conditions $(\lambda=1.2)$. Both reactors are operated at a pressure of 6 bar, allowing a pressure loss in subsequent process steps prior to the gas engine. Heat losses for both fluidized beds are considered, too.

The flue gas exits the combustion fluidized bed with a temperature of $850{ }^{\circ} \mathrm{C}$. Gradual cooling in heat exchangers to $100{ }^{\circ} \mathrm{C}$ provides the required process heat for air preheating and steam production.

Gas cleanup for the product gas is carried out in a cold gas cleaning section. Raw synthesis gas is stepwise cooled down to $30^{\circ} \mathrm{C}$ during the separation of tar and subsequent deposition of miscellaneous contaminations. No further pressurization is needed as the gasifier supplies the required pressure level to overcome losses during the cleaning section. The cleaning steps are modeled as simple separators. Water is condensed and separated.

\section{3 $\mathrm{SNG}$ production}

The SNG route (options D and E) contains a gas cleaning, methanation, and final conditioning part. Figures 5 and 6 show the general outline of the combined SNG process simulation flowsheet. The gas upgrading part of the flowsheet (Fig. 6) is mounted downstream of the fluidized bed gasifier connected at the indicated point marked by an asterisk (see Figs. 5 and 6).

Hot gas cleaning is modeled as a promising but still challenging technology, not yet state-of-the-art. Starting with the product gas at 5 bar from the fluidized bed gasifier, the SNG unit first leads to a tar-cracking reactor modeled as an RGibbs equilibrium reactor at $800^{\circ} \mathrm{C}$ with REA $\left(-100^{\circ} \mathrm{C}\right)$ so that the main gas composition does not change from the gasifier outlet composition. The naphthalene, however, is set to chemical equilibrium. Together with the tar, also the methane content decreases considerably (due to chemical equilibrium). After cooling down to $300{ }^{\circ} \mathrm{C}$, the synthesis gas is fed to an adsorber, where sulfur and chloride components are removed. The clean synthetic gas is then mixed with some additional water vapor in order to avoid carbon formation in the methanation reactor. The methanation reactor is modeled as near-isothermal at $260{ }^{\circ} \mathrm{C}$. The heat produced during the exothermal reaction is used for the vaporization of process water. After methanation, the raw SNG is further conditioned $\left(\mathrm{H}_{2} \mathrm{O}\right.$ and $\mathrm{CO}_{2}$ removal) to meet grid injection quality before compression up to 8 bar.

\subsection{Process parameter definition and input specifications}

The default state for all educts is ambient condition $\left(15^{\circ} \mathrm{C}\right.$ and 1 bar). Biomass compositions are taken from the Biobib database (Vienna University of Technology) [8]. Table 2 shows the elementary composition of biomass used for the simulation (beech wood).

The biomass further consists of $80 \mathrm{wt} \%$ volatiles and $19.39 \mathrm{wt} \%$ bound carbon with a higher heating value of $18,659 \mathrm{~kJ} / \mathrm{kg}$ (dry). Moisture content of the untreated biomass is set to $20 \mathrm{wt} \%$.

Power generation is handled as a black-box-unit via combined heat and power (CHP) as an established and available technology with defined electrical efficiency of 0.4 , which is quite a conservative value. Heat losses and pressure drops are defined according to the literature and calculations, e.g., for the heat loss through the reactor walls (5.2\% fluidized bed and $14.1 \%$ fixed bed due to pressure and temperature levels).

\section{Results and discussion}

In general, the simulation results are in good agreement with the literature data. Table 3 shows an overview of
Fig. 6 Simplified process simulation flowsheet of SNG production process (the asterisk indicates the link to the gasifier in Fig. 5)

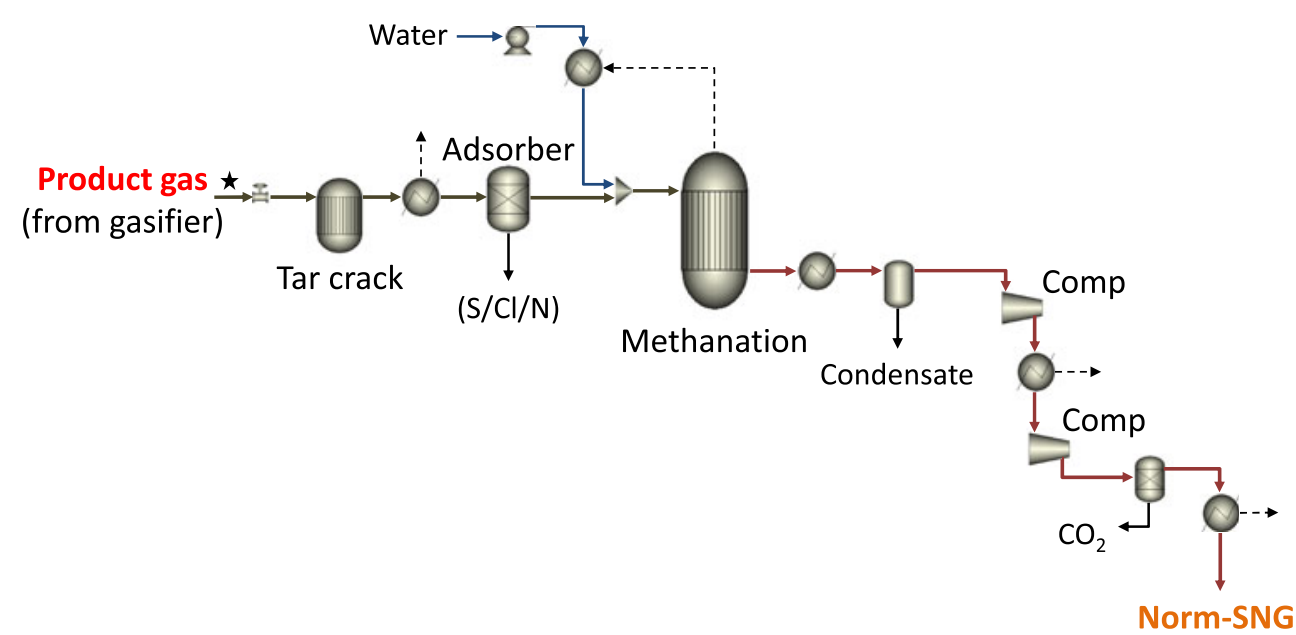


Table 2 Biomass composition (from BIOBIB, Vienna University of Technology 2010) [8]

\begin{tabular}{lllllll}
\hline Element & $\mathrm{C}$ & $\mathrm{H}$ & $\mathrm{O}$ & $\mathrm{N}$ & $\mathrm{S}$ & Ash \\
\hline $\mathrm{wt} \%$ (dry) & 47.97 & 5.78 & 45.39 & 0.22 & 0.03 & 0.61 \\
\hline
\end{tabular}

representative data from simulations (notations A-E are taken from Table 1 in Chapter 2).

Gas compositions strongly depend on the gasification technology. Only the dual fluidized bed technology is suitable for further SNG conversion as there is nearly no dilution with nitrogen from air. Fluidized bed option (C) has a much higher lower heating value (LHV) compared to the fixed bed options (A and B) and the highest cold gas efficiency $(72.2 \%)$. However, the mass flow (also volume flow) of product gas is much smaller for the fluidized bed.

SNG composition shows only small amounts of unwanted components $\left(3.8 \% \mathrm{H}_{2}, 2.8 \% \mathrm{CO}_{2}\right.$, and $\left.1.8 \% \mathrm{~N}_{2}\right)$. The conversion of synthesis gas to SNG (options D and E) leads to the smallest product gas output $(6,254.1 \mathrm{~kW})$ due to the second conversion process and various cleaning steps. The output gas meets the German regulations for injection into the natural gas grid [9] and is pressurized to 8 bar.

\subsection{Process efficiency}

For the base options with combined heat and power generation in a gas engine, simulation results are shown in Fig. 7 indicating overall, (net) cold gas and electrical efficiencies.

Efficiencies are defined based on the following equations:

$$
\begin{gathered}
\eta_{\text {cold gas }}=\frac{\dot{m}_{\text {product gas }} \times \mathrm{LHV}_{\text {product gas }}}{\dot{m}_{\text {biomass }} \times \mathrm{LHV}_{\text {biomass }}} \\
\eta_{\text {net }}=\frac{\dot{m}_{\text {product gas }} \times \mathrm{LHV}_{\text {product gas }}-P_{\text {int }}}{\dot{m}_{\text {biomass }} \times \mathrm{LHV}_{\text {biomass }}} \\
\eta_{\text {overall }}=\frac{\eta_{\mathrm{el}} \times \dot{m}_{\text {product gas }} \times \mathrm{LHV}_{\text {product gas }}+\eta_{\text {heat }} \times \dot{Q}_{\text {use }}-P_{\text {int }}}{\dot{m}_{\text {biomass }} \times \mathrm{LHV}_{\text {biomass }}} \\
\eta_{\mathrm{el}}=\frac{P_{\text {electrical,net }}}{\dot{m}_{\text {biomass }} \times \mathrm{LHV}_{\text {biomass }}}
\end{gathered}
$$

Internal power consumption $\left(P_{\text {int }}\right)$ is provided by the utilization of product gas with an electrical efficiency of 0.4 . The power consumption covers the final pressurization of SNG to 8 bar (options D and E).

For overall efficiency, heat above a level of $60{ }^{\circ} \mathrm{C}$ is considered to be usable in any further industrial process or the local heat grid. Gas engines are assumed with an electrical efficiency of $40 \%$ and a thermal efficiency of $50 \%$. A heat utilization factor of 0.9 is assumed for the calculation of overall efficiency.

The highest overall efficiencies are achieved both with fluidized bed gasification ( $73.7 \%$ ) and the SNG solution D $(71.2 \%)$, whereas the small difference is caused by the natural gas grid losses only. The highest net cold gas efficiency is reached with the fluidized bed option (63.1\%). This is mainly caused by higher internal consumption for compressors in the fixed bed options A and B. The SNG option has lower net cold gas efficiency because of the cleaning and separation steps.

\subsection{Importance of heat utilization}

A critical factor is the on-site heat utilization by the gasifier. Due to low electrical efficiencies in small-scale applications, heat utilization is essential to achieve high overall energetic efficiency and economic profitability.

Besides total efficiencies, more information can be drawn from an overall evaluation including heat utilization and local heat sinks, respectively. Therefore, the following scenarios are considered:

- Options A, B, and C as described above, with a gas engine (CHP) directly mounted to the gasifier. As the gas engine is directly coupled to the gasifier (operated at full load), a constant heat consumer with high capacity is required onsite. In all of these cases, the total amount of heat (process heat and the engine's waste heat) produced at the gasifier location is significantly higher than for the SNG option.
Table 3 Product gas composition and parameters

\begin{tabular}{lcccc}
\hline & $\mathrm{A}$ & $\mathrm{B}$ & $\mathrm{C}$ & $\mathrm{D} / \mathrm{E}$ \\
\hline Composition (mol\%) & & & & \\
$\mathrm{H}_{2} \mathrm{O}$ & 0.6 & 0.6 & 0.6 & 0.0 \\
$\mathrm{H}_{2}$ & 11.1 & 15.0 & 44.3 & 3.8 \\
$\mathrm{CO}$ & 22.0 & 21.2 & 22.8 & 0.0 \\
$\mathrm{CO}_{2}$ & 11.0 & 12.5 & 21.3 & 2.8 \\
$\mathrm{CH}_{4}$ & 2.5 & 2.5 & 10.4 & 91.6 \\
$\mathrm{~N}_{2}$ & 52.9 & 48.2 & 0.5 & 1.8 \\
Mass flow product gas (kg/s) & 1.72 & 1.56 & 0.53 & 0.14 \\
LHV product gas (kJ/kg) & 4,102 & 4,506 & 13,739 & 45,043 \\
Synthesis gas output (kW) & 7,056 & 7,020 & 7,220 & 6,254 \\
Cold gas efficiency & $70.6 \%$ & $70.2 \%$ & $72.2 \%$ & $62.5 \%$ \\
\hline
\end{tabular}


Fig. 7 Efficiencies of process options $A-E$

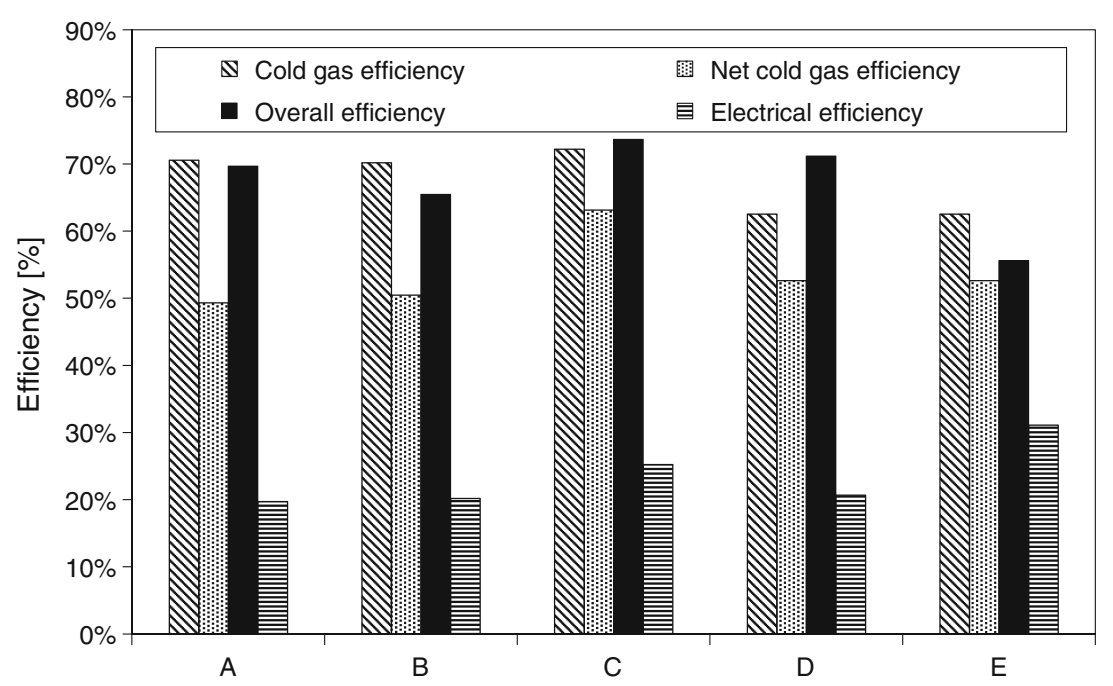

- Option D, with the injection of SNG into the natural gas grid and small-scale CHP generation (not at the gasifier location), adjusted to local heat demand and heat driven (overall efficiency of $90 \%$ from SNG). Waste heat utilization at the gasifier location is variable depending on the consumer.

- Option E, where SNG is injected into the natural gas grid and transferred to an efficient, large-scale combined cycle power plant (CCPP). Due to co-combustion of SNG, an electrical efficiency of $60 \%$ [10] is feasible. However, only process heat at the gasifier location can be used.

In the case of SNG injection (D and E), a gas loss of $1.5 \%$ is assumed for transfer through the gas grid. Due to the storage capacity of the grid, power production in option E and heat utilization from the small CHP units (D) can be adjusted to the current demand.

Figure 8 shows the influence of heat utilization at the gasifier on overall efficiencies for the above-mentioned scenarios. Available heat values for each option and resulting heat maximum, respectively, are listed in Tables 4 and 5,

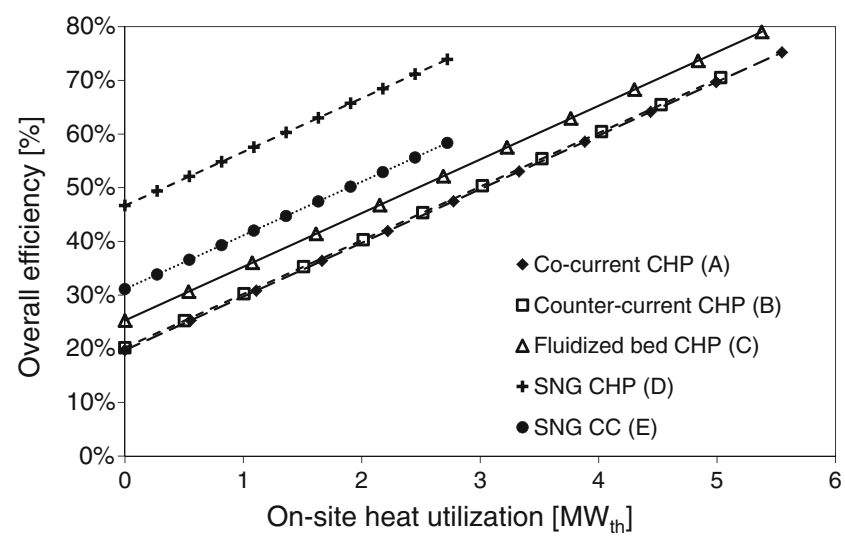

Fig. 8 Overall efficiencies of the gasification technologies with varying on-site heat utilization distinguished by location (on- and off-site heat utilization). For options A, B, and C, the entire heat accumulates on the site of the gasifier, in which the process heat accounts for about $30-40 \%$ while the rest is the engine's waste heat. Options D and E show a small on-site heat production (process heat only), but in option $\mathrm{D}$, the waste heat from the external CHP can be used in addition.

As derivable from Fig. 8, for small amounts of heat demand on-site $(<2.7 \mathrm{MW})$, the SNG options with injection of SNG into the natural gas grid and power generation in an off-site CCPP or CHP are the most efficient solution by far. The power generation in a combined cycle $(\mathrm{CC})$ power plant improves the overall efficiency for small heat utilization factors but stays below the SNG CHP option. That is because both local process heat from the SNG production and gasification waste heat are used.

Figures 7 and 8 also show the efficiencies for mere power generation without the use of any heat (heat utilization=0). However, the SNG CHP option (D) in Fig. 8 cannot be considered here because the engine's waste heat is already included in the calculation as it is not on-site. The highest electrical efficiency is reached with the SNG CC route

Table 4 Economic results for fixed bed gasification (options A and B)

\begin{tabular}{lrr}
\hline Option & \multicolumn{1}{l}{ A } & \multicolumn{1}{c}{ B } \\
\hline Investment total $(€)$ & $4,643,701$ & $4,643,701$ \\
Capital costs (annuity) (€/year) & 404,859 & 404,859 \\
Biomass costs ( $€ /$ year) & $1,714,787$ & $1,714,787$ \\
Repairs and servicing (€/year) & 69,656 & 69,656 \\
Personnel costs ( $€$ year) & 320,000 & 320,000 \\
Insurance and others (€/year) & 46,437 & 46,437 \\
Sum annual costs (€/year) & $2,555,738$ & $2,555,738$ \\
Net power (kW) & 1,973 & 2,019 \\
On-site heat utilization $(\mathrm{kW})$ & 5,548 & 5,031 \\
Off-site heat utilization $(\mathrm{kW})$ & 0 & 0 \\
\hline
\end{tabular}


Table 5 Economic results for fluidized bed gasification and SNG (options $\mathrm{C}, \mathrm{D}$, and $\mathrm{E}$ )

\begin{tabular}{lrrr}
\hline Option & C & D & \multicolumn{2}{l}{ E } \\
\hline Investment total $(€)$ & $11,944,081$ & $15,405,427$ & $16,055,545$ \\
Capital costs (annuity) (€/year) & $1,041,339$ & $1,343,115$ & $1,399,796$ \\
Biomass costs (€/year) & $1,714,787$ & $1,714,787$ & $1,714,787$ \\
Repairs and servicing (€/year) & 179,161 & 231,081 & 240,833 \\
Personnel costs ( $€ /$ year) & 320,000 & 320,000 & 320,000 \\
Insurance and others (€/year) & 119,441 & 154,054 & 160,555 \\
Sum annual costs (€/year) & $3,374,728$ & $3,763,038$ & $3,835,971$ \\
Net power (kW) & 2,526 & 2,106 & 3,111 \\
On-site heat utilization $(\mathrm{kW})$ & 5,377 & 2,722 & 2,722 \\
Off-site heat utilization $(\mathrm{kW})$ & 0 & 2,593 & 0 \\
\hline
\end{tabular}

$(31.1 \%)$ due to the highly efficient CC power generation. The fluidized bed route (C) results in an electrical efficiency of $25.3 \%$, and fixed bed options are only around $20 \%$ (A and B).

If a constant heat consumer with high capacity $\left(>4 \mathrm{MW}_{\text {th }}\right)$ is available at the gasifier site, options $\mathrm{A}-\mathrm{C}$ are promising concepts (e.g., it does not make sense, to consider SNG production, if there is a constant heat sink of about $5 \mathrm{MW}$ at the gasifier location). In this case, the overall efficiency is in the range or even above the SNG options, and lower investment and operation costs are expected. A crucial parameter for selecting the technology is the potential heat utilization at the location of the gasifier.

Small-scale applications vitally need an efficient utilization of waste heat. With increasing heat utilization, the energetic efficiencies of all options improve markedly. By using the natural gas grid, the heat and power production from SNG is decoupled from biomass gasification and can be adapted to the local demand.

\section{Economic considerations}

The economic evaluation is based on the German guideline VDI 2067 [11] and realized as a static calculation. The production costs for electricity are calculated depending on the on-site heat utilization.

Selected economic parameters are the interest rate $z=0.06$ and the observation period $T=20$ years. The following equation is used to calculate the annuity factor 0.0872 :

$a=\frac{z}{1-(1+z)^{-T}}$

For the annual expense of repairs and servicing, $1.5 \%$ of the investment and $1 \%$ for insurance and other costs are assumed, respectively. As operational staff for the $10 \mathrm{MW}_{\text {th }}$ plant, eight persons (three shifts) are calculated, each at $40,000 € /$ year.
The fuel costs are estimated at $90 € / \mathrm{t}(2.45 €$-ct $/ \mathrm{kWh}$ fuel $)$ based on the German fuel market in 2010 and 2011. Full operating hours are assumed to be 7,000 h/year, which correlates with practical experience, e.g., from Güssing [12].

The investment includes the gasifier with all necessary auxiliary components for operation, a gas cleaning unit for particles, gas compression, $\mathrm{H}_{2} \mathrm{~S}$ and $\mathrm{HCl}$ removal, and in the case of SNG production, additional gas cleaning for tars, a methanation and $\mathrm{a} \mathrm{CO}_{2}$ separation unit, and finally the costs for a CHP or CC power plant. The costs for the CCPP are assumed to be $500 € / \mathrm{kW}_{\mathrm{el}}$ (co-combustion) and for the CHP $430 € / \mathrm{kW}_{\mathrm{el}}$, respectively.

Investment costs are based on [13-16]. Tables 4 and 5 give an overview of the costs.

Power production costs are calculated according to the following equation:

$c_{\mathrm{el}}=\frac{c_{\mathrm{a}}-r_{\mathrm{on}}-r_{\mathrm{off}}}{Q_{\mathrm{el}}} \times 100$

The result, depending on the on-site heat utilization, is given in Fig. 9 for an exemplary heat revenue of $40 € / M W h$ heat.

The results of the analysis can be summarized in the following findings:

- For all concepts and particularly the CHP concepts, the on-site heat utilization is very important as power production costs can differ by more than $10 €$-ct $/ \mathrm{kWh}_{\mathrm{el}}$.

- Due to lower investments, production costs for fixed bed gasifiers are very low (options A and B). But from a technical point of view, an annual operation of 7,000 h/year is at least very ambitious for this technology.

- SNG CHP (D) performs worst mainly because of lower power production [compared to $(\mathrm{C})]$ and high investment costs.

- The production of SNG and co-combustion in a highly efficient CCPP (E) can be more economical than the application of a SNG CHP (D) or a fluidized bed CHP option (C). However, the economic result is strongly dependent on the revenues for heat.

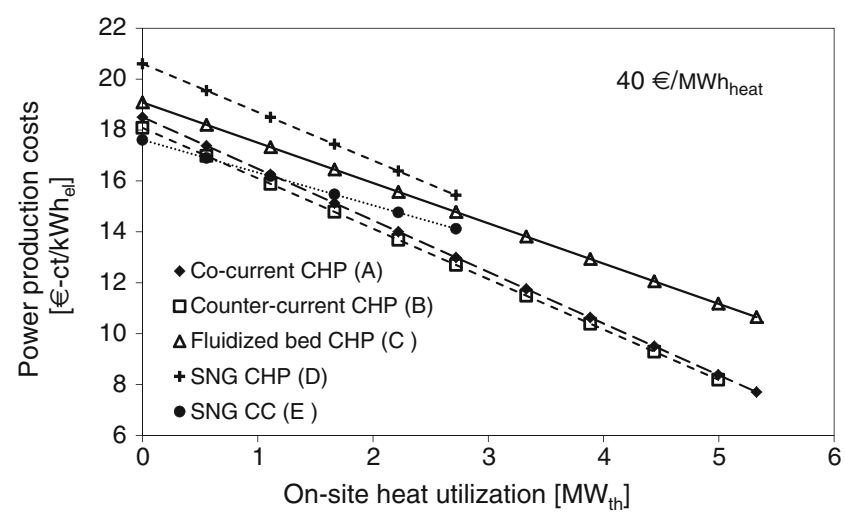

Fig. 9 Power production costs with varying on-site heat utilization 
- Further variations in heat revenues show the advantages of SNG production at low revenues for the heat.

- In general, the power production costs are within a comparable range for all options, differing by no more than $3.0 €-\mathrm{ct} / \mathrm{kWh}_{\mathrm{el}}$.

\section{Conclusion and outlook}

The concept evaluation and simulation clearly shows a potential for SNG production from biomass gasification both at low revenues for heat or if only low heat utilization is possible on-site. The benefits are related to high conversion efficiency, flexibility in power production, and more efficient heat utilization. In this regard, the SNG pathway is very attractive in comparison to other state-of-the-art technologies like Organic Rankine Cycles or steam cycles [17].

For small-scale applications in general, a maximized utilization of the released process heat results in a strong overall efficiency increase. Depending on the local heat utilization, gasification with subsequent methanation and grid injection has an advantage compared to local power generation.

The overall efficiency of the SNG option is found to be up to $73.9 \%$ (with $100 \%$ heat utilization), which is in the range of the fluidized bed gasification option. The crucial factor for high efficiency, and thus for economic operation, is the heat demand at the location of the gasifier. With even a small constant heat demand, the SNG solution becomes very competitive as some of the heat is virtually translated into chemical energy and carried to a power generation location elsewhere.

It has been shown that the SNG production subsequent of a small-scale fluidized bed gasifier can be efficient in both energetic and economic regards. The most important and crucial parameters are the local heat demand characteristics.

\section{References}

1. Kopyscinski J, Schildhauer TJ, Biollaz S (2010) Production of synthetic natural gas (SNG) from coal and dry biomass-a technology review from 1950 to 2009. Fuel 89:1763-1783
2. Rönsch St, Dreher M, Vogel A, Kaltschmitt M (2008) Erdgassubstitut aus biogenen Festbrennstoffen. VGB Powertech 5:110-116

3. Van der Meijden CM, Veringa HJ, Rabou L (2010) The production of synthetic natural gas (SNG): a comparison of three wood gasification systems for energy balance and overall efficiency. Biomass Bioenergy 34:302-311

4. Wang L, Weller CL, Jones DD, Milford AH (2008) Contemporary issues in thermal gasification of biomass and its application to electricity and fuel production. Biomass Bioenergy 32:573-581

5. Gassner M, Maréchal F (2009) Thermo-economic process model for thermochemical production of synthetic natural gas $(\mathrm{SNG})$ from lignocellulosic biomass. Biomass Bioenergy 33:1587-1604

6. Tremel A, Stemann M, Gaderer M, Spliethoff H (2009) Process efficiency of small scale SNG production from biomass. 17th European Biomass Conference \& Exhibition, Hamburg

7. Pröll T, Hofbauer H (2008) Development and application of a simulation tool for biomass gasification based processes. Int $\mathrm{J}$ Chem React Eng 6:A89

8. University of Technology Vienna (2010) Biofuels database BIOBIB. http://www.vt.tuwien.ac.at/biobib/wood.html. Accessed 17 May 2011

9. DVGW (2004) Technische Regeln Arbeitsplatt G262, November 2004

10. E.ON Kraftwerke GmbH (2011) Kraftwerk Irsching, http:// www.kraftwerk-irsching.com/pages/ekw_de/Kraftwerk_Irsching/ Mediencenter/ documents/pdf eon kraftwerke irsching.pdf. Accessed 14 December 2011

11. Verein deutscher Ingenieure (VDI) (2000) Economic efficiency of building installations-Fundamentals and economic calculations. VDI 2067 part 1, Düsseldorf 2000

12. Rauch R (2011) Development of the biomass CHP Güssing to a biosyngas platform. GreenSyngas consortium meeting in Güssing, Austria, 22-23 February 2011

13. Baumeister U (2006) Gaserzeugung aus fester BiomasseMarktfähigkeit heute. Gesellschaft für Nachhaltige Stoffnutzung mbH, http://www.tll.de/ainfo/pdf/mdebioet/btf10 06.pdf. Accessed 19 Dec 2011

14. Pörner (2008) Biofuel of 2nd Generation: EDL finishes project for CHOREN. http://www.poerner.at $/ 80.0 . h t m l$ ? \&L=2. Accessed 19 Dec 2011

15. Vogel A, Bolhàr-Nordenkampf $M$, Kaltschmitt $M$, Hofbauer $H$ (2006) Analyse und Evaluierung der thermo-chemischen Vergasung von Biomasse. Fachagentur für Nachwachsende Rohstoffe, Schriftreihe "Nachwachsende Rohstoffe" Band 29

16. ASUE e.V. (2011) BHKW-Kenndaten 2011. http://asue.de/cms/ upload/broschueren/2011/bhkw-kenndaten/asue-bhkw-kenndaten0311.pdf. Accessed 19 Dec 2011

17. Zweiler R (2008) Energiesysteme der Zukunft-Energetisch und wirtschaftlich optimierte Biomasse-Kraft-Wärmekopplungssysteme auf Basis derzeit verfügbarer Technologien. Projektnummer 812771, Renet-Kompetenzknoten Güssing-Forschungsinstitut für erneuerbare Energie $\mathrm{GmbH}$ 